\title{
Who Stays, Who Switches: Different Segments of Internet Service Customers
}

\section{Park Thaichon}

S P Jain School of Global Management, Australia

\author{
Antonio Lobo \\ Department of Management and Marketing, Swinburne University of Technology, \\ Australia
}

\section{Ann Mitsis}

Department of Management and Marketing, Swinburne University of Technology, Australia

\begin{abstract}
High-tech services providers such as Internet Service Providers (ISPs) are facing many challenges and high switching rates remain one of the top concerns. Despite significant research done in the area of switching intention in the marketing literature, customer segmentation and its relationship with switching intention appears to be overlooked. This study aims to fill this gap in the Telecommunication industry by exploring the switching intention and perceptions of different ISP customers. Data was obtained from 2,059 Internet users located in all regions of Thailand via an online survey. This study identified three major distinctive groups of ISP customers based on their Internet usagewhich were classified as light, medium and heavy users. This study also explored the differences among light, medium and heavy users in terms of age groups, employment status, gender and area of employment. The motivations associated with particular types of behaviour of each segment are also discussed.
\end{abstract}

Keywords: Segmentation, Behavioural Intentions, Switching Intention, Internet Service Providers (ISPs). 


\section{Introduction}

Customer switching is considered a major issue for many businesses and in this respect, businesses providing high-tech services such as Internet Service Providers (ISPs) are not an exception. ISPs are organisations that provide services for Internet related access, usage, and participation (Heckmann, 2007). An example of an ISP is True Internet in Thailand, a leading information and communications technology company providing Internet solutions to businesses and home users (ETDA, 2013). The customers of ISPs are either businesses or individuals who purchase Internet services. This study is targeted towards individual customers who purchase Internet services for use in their homes.

As the customers become the main focus of many business operations, service providers have put considerable effort in acquiring and retaining their customers. They generally do this by providing their customers with superior service delivery and performance. Zeithaml, Berry, and Parasuraman (1996) articulated that service quality influences various behavioural intentions including complaining, recommendation and switching intentions. Zeithaml and Bitner (2003) demonstrated that superior service quality results in customers' recommendations. This in turn strengthens the relationships between customers and businesses and helps in acquiring new customers. Businesses are concerned that their customers are switching to their competitors. In the telecommunications market, customers generally display low levels of loyalty and are essentially price conscious (Marketline, 2014). Hence, they are more prone to switching between the available service providers. It is predicted that a decline in brand loyalty and an increase in churn rates are likely to be the norm in this market in the coming years (Marketline, 2014). As customer loyalty has been extensively investigated in the marketing literature (Aydin and Özer, 2005; Chiou, 2004; Thaichon, Lobo, and Mitsis, 2014), this study endeavours to examine the effects of service quality dimensions on customers' behavioural intentions including those associated with intentionto switch.

Also, there is scant academic research relating to customers' characteristics in the residential Internet services market. As these customers have different needs, wants and desires, they are not a homogenous group; hence, it is necessary to segment the market in order to better service the target audience (Mazzoni, Castaldi, and Addeo, 2007). Segmentation enables service providers to maximise the use of their resources and capabilities to take advantage of existing opportunities and obtain more frequent customers (Weinstein, 1987). Despite the fact that the market segmentation concept has been reviewed comprehensively in the literature (Mazzoni et al., 2007; Wedel and Kamakura, 2003), there is scarce empirical evidence on how Internet service providers can effectively segment their target audience. In this study customers are categorised based on their Internet usage pattern, which is considered one of the most rational basis of segmentation (Mazzoni et al., 2007; Wedel and Kamakura, 2003). By allocating customers to different usage categories, service providers can develop effective and efficient marketing strategies for each segment. Such an approach is in line with Weinstein's (2001) findings which indicate that usage analysis can significantly support customer retention scheme.

The competition in Thailand among residential Internet service providers is intense. Currently there are three majors ISPs and sixteen smaller ones across the country 
(Thaichon and Quach, 2013). In this highly competitive market, the churn rate of Internet users was approximately $12 \%$ in 2009 and is predicted to be above $20 \%$ by 2017. This scenario, therefore, poses a large challenge to ISPs especially in the area of customer retention.

This research aims to explore the characteristics and perceptions of customers of Internet Service Providers (ISPs) in order to provide a general picture of ISP subscribers and to enable more customer-focused marketing strategies, especially with regards to customer switching intention. In particular, the findings of this study can be utilised by ISPs to design effective customer retention strategies, which would increase their profitability.

\section{Literature Review}

\section{Customer Switching Intention}

The rising competition in the global market means that it becomes increasingly important for businesses to preserve their existing customers. Switching intentionis considered a significant factor in all businesses, especially in the services sector. Switching intention in this research refers to the possibility that customers will change their current service provider. Understanding switching intention could help in retaining current customers (Wan-Ling and Hwang, 2006). As such, businesses are highly concerned with drivers of switching intention.

In the telecommunications industry, retaining existing customers is less expensive than recruiting new customers (Thaichon et al., 2014). Attracting new customers costs around five times more than retaining current customers (Christodoulides and Michaelidou, 2010). Spiller, Vlasic, and Yetton (2007) claim that a 1\% increase in the customer retention rate could add approximately $5 \%$ profit to an ISP, which also eases the stress of finding and acquiring new customers. In addition, a 2\% growth in the customer retention rate is equivalent to a $10 \%$ decrease in the cost of customer acquisition (Han, Lu, and Leung, 2012). Hence, it is essential for ISPs to investigate and understand customer loyalty and retention by examining consumption behaviour. This knowledge can help to maintain and even improve the company's market share and profitability.

A number of previous researchers have attempted to explain the causes of switching and switching intention. For example, Wen-Hua et al., (2010) claimed that switching costs and attractiveness of alternatives had a strong influence on switching intention. Saeed, Hussain and Riaz (2011) reported that price, perceived commitment and outcome quality could affect customers' intention to switch. Thaichon and Quach (2016) proposed that sales promotion had an impact on customer switching costs which lead to switching intention. Although many researchers have explored the switching intention literature, very limited research has explored different customer segments. This study aims to fill this gap in the telecommunication industry.

\section{Segmentation}

Customer relationships need to be maintained and strengthened over time (Cooil, Keiningham, Aksoy, and Hsu, 2007; Czepiel, 1990). Altman and Taylor (1973) state 
that relationships develop from lower to more significant levels as interactive parties gain more experience. Previous studies assert that loyalty varies as a function of customer experience in the services context (Tracey, Dagger, and O'Brien, 2010). As experience accumulates, customers tend to have multiple interactions with the firm and the service, and gain more information, such as associated benefits and outcomes of the relationship. Hence an increase in experience has significant impact on customer behaviour (Larkin, McDermott, Simon, and Simon, 1980; Maheswaran and Sternthal, 1990).

One fundamental dimension of experience is usage (Dahlen, 2002). The attribute evaluability theory underpins the effects of experiences (Hsee, 1996). This theory posits that experts have more advanced conceptual knowledge and are in a better position to comprehend the meaning of service information as well as benefits obtained as compared to novice consumers (Alba and Hutchinson, 1987). Furthermore, novices and experts are more likely to assign different levels of importance to the same set of service attributes (Alba and Hutchinson, 1987; Dagger and Sweeney, 2007). In the context of Internet services, customers are generally segmented as heavy, medium and light users on the basis of their usage which is also an indicator of their experience with the ISP. Light users as novices are less familiar with technical issues and are often unable to fathom the implications of relevant information. Hence, they may pay more heed to attributes associated with convenience rather than actual importance (Dagger and O'Brien, 2010). This suggests that service quality dimensions that are important to light users might not be significant for more experienced customers (e.g. heavy users). As a result, the influence of these service attributes on customers' behavioural intentions is likely to vary across different Internet usage groups.

Segmentation is considered as an aid to customer retention strategies (Weinstein, 2002). As customers have different needs, wants and desires, they are not homogenous. Hence, it is necessary to segment the market in order to provide better services to the target audience (Mazzoni et al., 2007). Although the market segmentation concept has been reviewed comprehensively in the literature (Mazzoni et al., 2007; Wedel and Kamakura, 2003), there is scant empirical evidence of how Internet service providers can effectively segment their target audience. In this study customers are grouped based on their Internet usage patterns (Mazzoni et al., 2007; Wedel and Kamakura, 2003). By grouping customers into various usage categories, service providers can strategise effectively and efficiently for each segment and as a result, are able to enhance customer retention (Weinstein, 2001).

On average, an Internet user spends from 9 hours to as much as 20 hours per week online (ACMA, 2012). Heavy users are those who spend more than 29 hours on the Internet every week, whilst light users are those who use the Internet for less than 9 hours per week (Assael, 2005). The number of heavy users is envisaged to rise in the future as the role of the Internet is becoming increasingly important. A study by the Electronic Transactions Development Agency (ETDA, 2013) revealed that Thai Internet users who spend less than 11 hours per week online account for 35.7 per cent; those who spend between 11 - 20 hours per week online make up 25.8 per cent; 10.7 per cent of Thai users spend $21-41$ hours on the Internet weekly; and 27.8 per cent spend more than 41 hours weekly. Adapting usage segmentation from previous research,this study identifies three main groups of Internet users including light (i.e. 
less than 9 hours per week), medium (i.e. 9 - 29 hours per week), and heavy users (i.e. more than 29 hours per week).

\section{Method}

Data was collected from residential Internet users located in all regions of Thailand through an online survey. Thailand is ranked third in South East Asia by way of residential Internet usage with an estimated 17,483,000 Internet users in 2009 (CIA, 2013) and over 24 million Internet users in 2012 (IWS, 2013). The number in 2012 represented over one-third of the Thai population. A selective customer database of three well-established ISPs in Thailand were utilised as the sampling frame. The chosen corporations are the dominant players in the Internet services market in Thailand with nationwide coverage, and hold more than $90 \%$ market share in total. This database included customers throughout Thailand who were not locked into any fixed term contract with the ISPs. Therefore, they were free to act as they desired, and their behavioural intentions could be more accurately investigated. It was a requirement that the participants were over 18 years of age and had used home Internet services. The survey instrument was administered online using the university's Opinio survey platform. Opinio supports a full range of question types and surveys with skip logic and piping. The web link of the online survey was relayed to Internet customers in the sampling frame. The survey platform was kept live for a period of three months. A total of 8000 surveys were distributed in all geographical regions of Thailand. The final usable sample size was 2059. Table 1 depicts the demographic profile of the respondents.

Table 1: Demographic profile of respondents

\begin{tabular}{lcc}
\hline Demographic profile & Number $(N)$ & Percent $(\%)$ \\
\hline Gender & & \\
$\quad$ Male & 1348 & 65.5 \\
$\quad$ Female & 711 & 34.5 \\
Age & 465 & \\
$\quad 18$ and 28 years & 797 & 22.6 \\
29 and 39 years & 510 & 38.7 \\
40 and 49 years & 287 & 13.8 \\
50 years or older & & \\
Household monthly income(Bath per month) & 92 & 5 \\
$\quad$ Under 10,000 & 537 & 26.1 \\
10,001 to 30,000 & 484 & 23.5 \\
30,001 to 50,000 & 503 & 24.4 \\
50,001 to 100,000 & 433 & 21 \\
$\quad$ Over 100,000 & & \\
Education & 117 & 5.7 \\
Secondary or below qualification & 175 & 8.5 \\
2 years college or associate degree & 1215 & 59 \\
Bachelor's degree & 552 & 26.8 \\
$\quad$ Postgraduate degree or higher & & \\
Employment status & 1302 & 63.2 \\
Full time & 48 & 2.3 \\
Part time/casual/seasonal & 506 & 24.6 \\
Self-employed & 146 & 7.1 \\
$\quad$ Retired & &
\end{tabular}


Table 1: Demographic profile of respondents (Cont'd)

\begin{tabular}{lcc}
\hline Demographic profile & Number $(N)$ & Percent $(\%)$ \\
\hline Number of people in a household & & \\
1 & 118 & 5.7 \\
2 & 396 & 19.2 \\
3 & 399 & 19.4 \\
4 & 557 & 27.1 \\
5 or more & 396 & 28.6 \\
\hline
\end{tabular}

\section{Analysis and Results}

\section{Usage Pattern of Internet Customers}

The results show that $61.5 \%$ of the total respondents had used some other Internet service provider in the past. In terms of reasons for changing service providers, the result showed that $23 \%$ of total respondents switched due to promotional packages, $27 \%$ due to poor Internet service performance, $15.3 \%$ due to high price, $26.5 \%$ due to poor customer service; and $14.6 \%$ mentioned other reasons, for example poor aftersales service, inflexible payment method sand lack of service coverage.

In terms of time spent on the Internet every week, $3.7 \%$ spent less than 2 hours, $24.9 \%$ spent 2 to 9 hours, $14.9 \%$ spent 10 to 19 hours, $8.1 \%$ spent 20 to 29 hours, and $48.5 \%$ spent more than 30 hours. A recent report indicated that the average time a person spends on the Internetis approximately 20 hours (Nielson, 2013), which is relatively consistent with the finding of this study. However, it is noticeable that almost half of the respondents in this study spent more than 30 hours on the Internet.This suggests that people tend to rely more on the Internet, which makes it a significant component of modern life.

\section{Segmentation of Internet Customers}

This study identified and examined three groups of customers: light, medium and heavy users. Heavy users (i.e. 48\%) are those who spend more than 30 hours on the Internet every week (Assael, 2005).Spending significant amounts of time on the Internet, heavy users distinguish themselves from the other two groups. The numbers in this specific segment is expected to increase as the role of the Internet becomes increasingly more important in human life. Similarly, it is expected that users in the other two categories will either stay static or decrease. Light users use the Internet for less than 9 hours per week (i.e. 29\%), and medium users (i.e. 23\%) spend from 9 to 29 hours online per week.

\section{Demographic Profile of Internet User Groups}

Light users tend to be between 29 - 39 years (i.e. $36.4 \%$ ) and 40 - 49 years old (i.e. $32.8 \%$ ), who are employed full time (Table 2). The distribution of age among medium users does not show any significant pattern. Interestingly it was revealed that more than $60 \%$ of heavy users belong to the $18-28$ age group. Beside, about $50 \%$ of the 29 - 39 age groups are classified as heavy users. 
From the employment status perspective (Table 2), more than $40 \%$ of pensioners are light users. This can be explained by the fact that retired people are usually old and not familiar with the technology (i.e. Internet) especially in the Asian context. In terms of gender, females are more likely to be light users than their male counterparts. The distribution of gender is also relatively even in this group of users.

Noticeably in Table 2, more than $50 \%$ of respondents the from Education and Training sector are identified as medium users while approximately 50\% of those in Administration and Office Support and Information Technology (IT) are identified as heavy users. This can be illuminated bythe fact that office workers, especially IT and HR staff,often work with computers, engaging in frequent communications via emailsas well asother online tasks.

Table 2: Age groups, employment status, gender and area of employment

\begin{tabular}{|c|c|c|c|c|c|c|}
\hline Age group & & & $18-28$ & $29-39$ & $40-49$ & $50>$ \\
\hline \multirow{4}{*}{ Light user } & Count & & 89 & 214 & 193 & 92 \\
\hline & $\begin{array}{l}\% \text { within Internet } \\
\text { usage }\end{array}$ & & $15.10 \%$ & $36.40 \%$ & $32.80 \%$ & $15.60 \%$ \\
\hline & $\begin{array}{l}\% \text { within Age } \\
\text { group }\end{array}$ & & $19.10 \%$ & $26.90 \%$ & $37.80 \%$ & $32.10 \%$ \\
\hline & $\%$ of Total & & $4.30 \%$ & $10.40 \%$ & $9.40 \%$ & $4.50 \%$ \\
\hline \multirow{4}{*}{ Medium user } & Count & & 94 & 165 & 129 & 85 \\
\hline & $\begin{array}{l}\% \text { within Internet } \\
\text { usage }\end{array}$ & & $19.90 \%$ & $34.90 \%$ & $27.30 \%$ & $18.00 \%$ \\
\hline & $\begin{array}{l}\% \text { within Age } \\
\text { group }\end{array}$ & & $20.20 \%$ & $20.70 \%$ & $25.30 \%$ & $29.60 \%$ \\
\hline & $\%$ of Total & & $4.60 \%$ & $8.00 \%$ & $6.30 \%$ & $4.10 \%$ \\
\hline \multirow{4}{*}{ Heavy user } & Count & & 282 & 418 & 188 & 110 \\
\hline & $\begin{array}{l}\% \text { within Internet } \\
\text { usage }\end{array}$ & & $28.30 \%$ & $41.90 \%$ & $18.80 \%$ & $11.00 \%$ \\
\hline & $\begin{array}{l}\% \text { within Age } \\
\text { group }\end{array}$ & & $60.60 \%$ & $52.40 \%$ & $36.90 \%$ & $38.30 \%$ \\
\hline & $\%$ of Total & & $13.70 \%$ & $20.30 \%$ & $9.10 \%$ & $5.30 \%$ \\
\hline $\begin{array}{l}\text { Employment } \\
\text { status }\end{array}$ & & Full time & Part time & $\begin{array}{c}\text { Self- } \\
\text { employed }\end{array}$ & $\begin{array}{c}\text { Un- } \\
\text { employed }\end{array}$ & Retired \\
\hline \multirow{3}{*}{$\begin{array}{l}\text { Light } \\
\text { user }\end{array}$} & Count & 413 & 12 & 107 & 33 & 23 \\
\hline & $\begin{array}{l}\% \text { within Internet } \\
\text { usage } \\
\% \text { within }\end{array}$ & $70.20 \%$ & $2.00 \%$ & $18.20 \%$ & $5.60 \%$ & $3.90 \%$ \\
\hline & $\begin{array}{l}\text { Employment } \\
\text { status }\end{array}$ & $31.70 \%$ & $25.00 \%$ & $21.10 \%$ & $22.60 \%$ & $40.40 \%$ \\
\hline \multirow{5}{*}{$\begin{array}{l}\text { Medium } \\
\text { user }\end{array}$} & $\%$ of Total & $20.10 \%$ & $0.60 \%$ & $5.20 \%$ & $1.60 \%$ & $1.10 \%$ \\
\hline & Count & 309 & 6 & 118 & 25 & 15 \\
\hline & $\begin{array}{l}\% \text { within Internet } \\
\text { usage } \\
\% \text { within }\end{array}$ & $65.30 \%$ & $1.30 \%$ & $24.90 \%$ & $5.30 \%$ & $3.20 \%$ \\
\hline & $\begin{array}{l}\text { Employment } \\
\text { status }\end{array}$ & $23.70 \%$ & $12.50 \%$ & $23.30 \%$ & $17.10 \%$ & $26.30 \%$ \\
\hline & $\%$ of Total & $15.00 \%$ & $0.30 \%$ & $5.70 \%$ & $1.20 \%$ & $0.70 \%$ \\
\hline
\end{tabular}


Table 2: Age groups, employment status, gender and area of employment (Cont'd)

\begin{tabular}{|c|c|c|c|c|c|c|}
\hline $\begin{array}{l}\text { Employment } \\
\text { status }\end{array}$ & & Full time & Part time & $\begin{array}{c}\text { Self- } \\
\text { employed }\end{array}$ & $\begin{array}{c}\text { Un- } \\
\text { employed }\end{array}$ & Retired \\
\hline \multirow{4}{*}{$\begin{array}{l}\text { Heavy } \\
\text { user }\end{array}$} & Count & 580 & 30 & 281 & 88 & 19 \\
\hline & $\begin{array}{l}\% \text { within Internet } \\
\text { usage }\end{array}$ & $58.10 \%$ & $3.00 \%$ & $28.20 \%$ & $8.80 \%$ & $1.90 \%$ \\
\hline & $\begin{array}{l}\% \text { within } \\
\text { Employment } \\
\text { status }\end{array}$ & $44.50 \%$ & $62.50 \%$ & $55.50 \%$ & $60.30 \%$ & $33.30 \%$ \\
\hline & $\%$ of Total & $28.20 \%$ & $1.50 \%$ & $13.60 \%$ & $4.30 \%$ & $0.90 \%$ \\
\hline \multicolumn{2}{|l|}{ Gender } & & Male & Female & & \\
\hline \multirow[t]{4}{*}{ Light user } & Count & & 357 & 231 & & \\
\hline & $\begin{array}{l}\% \text { within Internet } \\
\text { usage }\end{array}$ & & $60.70 \%$ & $39.30 \%$ & & \\
\hline & $\%$ within Gender & & $26.50 \%$ & $32.50 \%$ & & \\
\hline & $\%$ of Total & & $17.30 \%$ & $11.20 \%$ & & \\
\hline \multirow[t]{4}{*}{ Medium user } & Count & & 317 & 156 & & \\
\hline & $\begin{array}{l}\% \text { within Internet } \\
\text { usage }\end{array}$ & & $67.00 \%$ & $33.00 \%$ & & \\
\hline & $\%$ within Gender & & $23.50 \%$ & $21.90 \%$ & & \\
\hline & $\%$ of Total & & $15.40 \%$ & $7.60 \%$ & & \\
\hline \multirow[t]{4}{*}{ Heavy user } & Count & & 674 & 324 & & \\
\hline & $\begin{array}{l}\% \text { within Internet } \\
\text { usage }\end{array}$ & & $67.50 \%$ & $32.50 \%$ & & \\
\hline & $\%$ within Gender & & $50.00 \%$ & $45.60 \%$ & & \\
\hline & $\%$ of Total & & $32.70 \%$ & $15.70 \%$ & & \\
\hline \multicolumn{2}{|c|}{ Area of employment } & Agriculture & $\begin{array}{c}\text { Education } \\
\text { Training }\end{array}$ & $\begin{array}{c}\text { Information } \\
\text { Technology }\end{array}$ & $\begin{array}{c}\text { Office } \\
\text { Support }\end{array}$ & $\begin{array}{c}\text { Hospitality } \\
\text { Tourism }\end{array}$ \\
\hline \multirow{5}{*}{ Light user } & Count & 4 & 42 & 75 & 202 & 93 \\
\hline & $\begin{array}{l}\% \text { within } \\
\text { Internet usage }\end{array}$ & $0.70 \%$ & $7.10 \%$ & $12.80 \%$ & $34.40 \%$ & $15.80 \%$ \\
\hline & $\%$ within Area & $21.10 \%$ & $25.90 \%$ & $22.70 \%$ & $28.70 \%$ & $33.20 \%$ \\
\hline & $\%$ of Total & $0.20 \%$ & $2.00 \%$ & $3.60 \%$ & $9.80 \%$ & $4.50 \%$ \\
\hline & Count & 8 & 82 & 86 & 158 & 61 \\
\hline \multirow[t]{3}{*}{ Medium user } & $\begin{array}{l}\% \text { within } \\
\text { Internet usage }\end{array}$ & $1.70 \%$ & $8.00 \%$ & $18.20 \%$ & $33.40 \%$ & $12.90 \%$ \\
\hline & $\%$ within Area & $42.10 \%$ & $50.60 \%$ & $26.00 \%$ & $22.50 \%$ & $21.80 \%$ \\
\hline & $\begin{array}{l}\% \text { of Total } \\
\text { Count }\end{array}$ & $\begin{array}{c}0.40 \% \\
7\end{array}$ & $\begin{array}{c}4.00 \% \\
38\end{array}$ & $\begin{array}{c}4.20 \% \\
170\end{array}$ & $\begin{array}{c}7.70 \% \\
343\end{array}$ & $\begin{array}{c}3.00 \% \\
126\end{array}$ \\
\hline \multirow[t]{3}{*}{ Heavy user } & $\begin{array}{l}\% \text { within } \\
\text { Internet usage }\end{array}$ & $0.70 \%$ & $8.20 \%$ & $17.00 \%$ & $34.40 \%$ & $12.60 \%$ \\
\hline & $\%$ within Area & $36.80 \%$ & $23.50 \%$ & $51.40 \%$ & $48.80 \%$ & $45.00 \%$ \\
\hline & $\%$ of Total & $0.30 \%$ & $1.80 \%$ & $8.30 \%$ & $16.70 \%$ & $6.10 \%$ \\
\hline
\end{tabular}

\section{Switching Intention}

This section examines the differences in customer retention of light, medium and heavy users. Kruskal - Wallis ANOVA tests were employed to examine switching intention of the three usage groups. The results in Table 3 indicate that there were statistically significant differences between light, heavy and medium users in their switching intention.

Table 3: Result of Kruskal - Wallis ANOVA tests Switching intention 


\begin{tabular}{cccc}
\hline Internet usage & Mean Rank & Chi-Square & Asymp. Sig. \\
\hline Light user & 970.95 & & \\
Medium user & 1042.16 & $\lambda^{2}(2)=8.94$ & 0.011 \\
Heavy user & 1059.03 & & \\
\hline
\end{tabular}

With regards to the switching experience and to the high churn rate experienced by this industry, it is not surprising that more than $50 \%$ of the respondents in this survey had used other ISPs before. However, it is noticeable that nearly $80 \%$ of heavy users agreed that they switched service providers previously, whereas only $63 \%$ of medium users and $58 \%$ of light users had experience with other ISPs. This confirms that heavy users are more likely to switch when compared with the other two segments. Moreover, the significance test (Table 3) also demonstrated that heavy users tend to exhibit higher intention to switch than light and medium users.

In terms of switching behaviour, more than $50 \%$ of heavy users chose poor service performance as the reason why they changed their service providers (Figure 1). The second reason was poor customer service followed by less promotional packages. Only $24 \%$ of heavy users switched because of price. It appears that customers belonging to this group of users focused more on the core performance of Internet service providers (i.e. 50.6\%). They were less concerned with the monetary cost or the promotional packages.

On the other hand, medium users were most likely to switch when they perceived poor service delivery(i.e. $41.5 \%$ ) or experienced bad customer service (i.e. $40.8 \%$ ). Light users appeared to be equally concerned with customer service (i.e. $40.3 \%$ ), poor Internet service performance (i.e. 39.1\%) and promotional packages (i.e. 39.1\%). It can be concluded that although heavy uses related their switching decision making predominantly with Internet performance, all the three groups consistently considered poor Internet service performance, poor customer service, and less promotional packages as the top three reasons to switch (Figure 1).

$\square$ Light users $\quad$ Medium users $\quad$ Heavy users

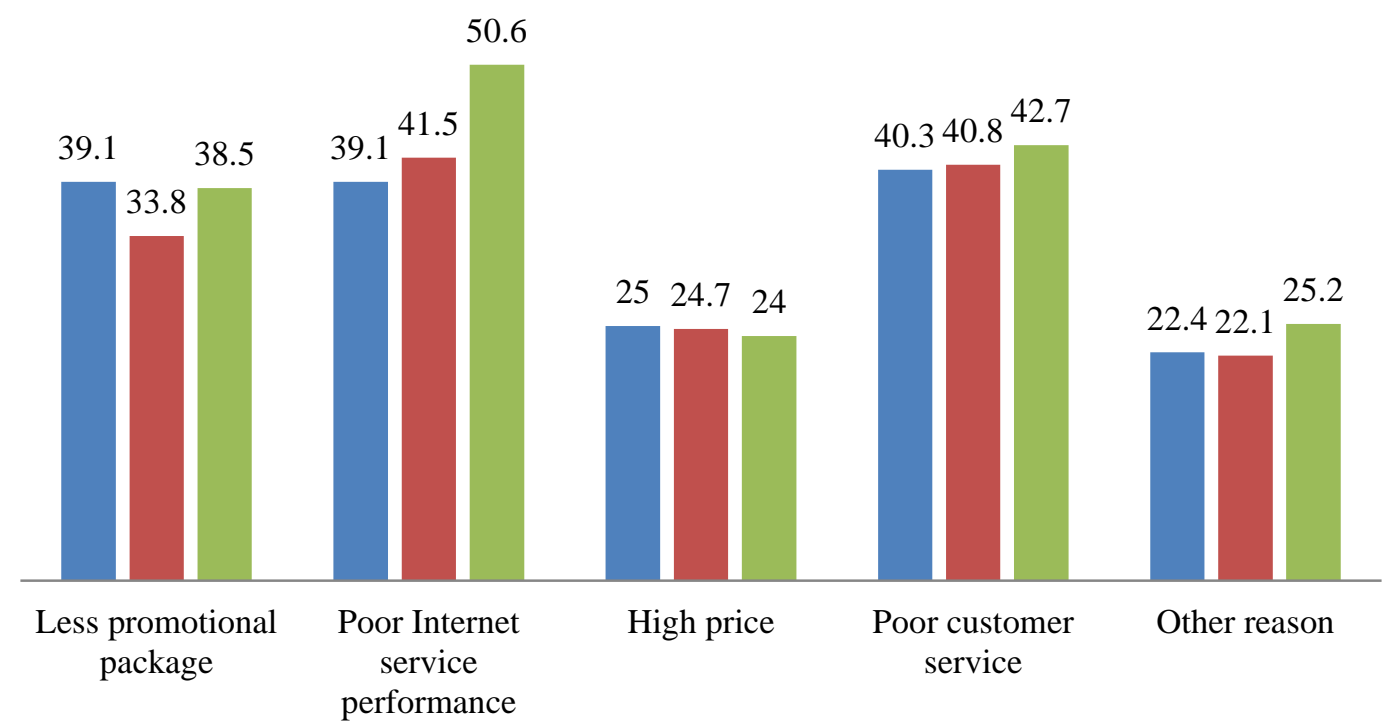

Figure 1: Reasons to switch 
Four main factors of service quality are network quality, customer service, information support and security and privacy. Multiple regression analyses were used to confirm the effects of service quality factors on the criterion variables (i.e. switching intention) across different groups of Internet users. Results from regressing switching intention against four service quality aspects are shown in Table 4. For all participants, perception of network quality, customer service, information support, and security and privacy was negatively related to switching intention. The core ISP service offering, network quality, was predominant in determining the intent to switch, whereas customer service, security and privacy issues were least influential. As expected, the effects of all four ISP service quality aspects on customers' intention to switch were different among light, medium and heavy users. Network quality was the most important factor in determining both medium users and heavy users' switching intention. In contrast, information support had the most significant influence on light users' intention to switch. Furthermore, it is noticed that customer service was only significantly and negatively associated with switching intention of heavy users. Following Prentice (2014), further analyses were undertaken to test the effects of service quality by dropping the factors that were not significantly related to the criterion variable (i.e. switching intention). Removing the non-significant predictors makes the model fit that dataset better and a more parsimonious model can be achieved. In addition, using more variables may lead to over-fitting a model (Crown, 1998). The findings were confirmed in these additional analyses. The beta values for these variables are shown in Table 4.

Table 4: Results for the relationships between customer perceptions of service quality, and intention to switch, beta coefficients

\begin{tabular}{|c|c|c|c|c|c|c|c|c|c|}
\hline & \multirow{2}{*}{ Total } & \multicolumn{4}{|c|}{ Intention to switch } & \multirow[t]{2}{*}{ Total } & \multicolumn{3}{|c|}{$\begin{array}{l}\text { Intention to switch (after dropping } \\
\text { insignificant factors) }\end{array}$} \\
\hline & & $\begin{array}{l}\text { Light } \\
\text { users }\end{array}$ & $\begin{array}{l}\text { Medium } \\
\text { users }\end{array}$ & \multicolumn{2}{|c|}{$\begin{array}{l}\text { Heavy } \\
\text { users }\end{array}$} & & $\begin{array}{l}\text { Light } \\
\text { users }\end{array}$ & $\begin{array}{l}\text { Medium } \\
\text { users }\end{array}$ & $\begin{array}{l}\text { Heavy } \\
\text { users }\end{array}$ \\
\hline NQ & $-.122 * * *$ & -.088 & $-.197 * *$ & \multicolumn{2}{|c|}{$-.119 * *$} & $-.122 * * *$ & & $-.280 * *$ & $-.159 * * *$ \\
\hline CS & $-.066^{*}$ & -.044 & -.005 & \multicolumn{2}{|c|}{$-.103 *$} & $-.066^{*}$ & & & $-.171 * * *$ \\
\hline IW & $-.100 * *$ & $-.168 * *$ & -.027 & \multicolumn{2}{|c|}{-.078} & $-.100 * *$ & $-.294 * * *$ & & \\
\hline SP & $-.078 * *$ & -.079 & -.109 & \multicolumn{2}{|c|}{-.063} & $-.078 * *$ & & & \\
\hline \multicolumn{5}{|c|}{ Model summaries for switching intention } & \multicolumn{5}{|c|}{$\begin{array}{l}\text { Model summaries for switching intention (after } \\
\text { dropping insignificant factors) }\end{array}$} \\
\hline \multicolumn{5}{|c|}{$\begin{array}{l}\mathrm{R}^{2}(\text { Total })=.092, \mathrm{~F}(4,2054)=51.979 \\
\mathrm{R}^{2}(\text { Light Users })=.1, \mathrm{~F}(4,583)=16.284 \\
\left.\mathrm{R}^{2} \text { (Medium Users }\right)=.089, \mathrm{~F}(4,468)=11.426 \\
\left.\mathrm{R}^{2} \text { (Heavy Users }\right)=.09, \mathrm{~F}(4,997)=24.572\end{array}$} & \multicolumn{5}{|c|}{$\begin{array}{l}\mathrm{R}^{2}(\text { Total })=.092, \mathrm{~F}(4,2054)=51.979 \\
\mathrm{R}^{2}(\text { Light Users })=.086, \mathrm{~F}(4,583)=55.416 \\
\mathrm{R}^{2} \text { (Medium Users) }=.078, \mathrm{~F}(4,468)=40.007 \\
\left.\mathrm{R}^{2} \text { (Heavy Users }\right)=.080, \mathrm{~F}(4,997)=44.450\end{array}$} \\
\hline
\end{tabular}

Notes: total $=$ coefficient values for all participants, $* \mathrm{p}<.05, * * \mathrm{p}<.01, * * * \mathrm{p}<.001$

Hours spent on Internet per week: light users $=$ under 9 hours; medium users $=9-29$ hours; heavy users $=$ more than 29 hours. $\mathrm{NQ}=$ network quality; $\mathrm{CS}=$ customer service; $\mathrm{IW}=$ information support; $\mathrm{SP}=$ security and privacy

\section{Discussion and Implications}

This research aimed to provide a holistic picture of customers in the home Internet services sector in Thailand. It has developed an understanding of consumption behaviour including customers' demographic profiles and switching behaviour with a view to achieving the foundation for customer retention strategies. It contributes towards a new body of knowledge with regards to the future potential of ISPs. This 
study highlights the importance of segmentation, and in this regard customers' usage patterns were addressed as one of the important bases of segmentation. Practically, ISPs need to consider customer usage patterns to serve their customers better.

The findings demonstrate that ISP customers are not homogeneous. As such, it is vital to understand customer characteristics in order to retain them. For instance, heavy users tend to have higher expectations when evaluating service quality aspects. They are most satisfied with security and privacy practice of their ISPs whereas information support receives the highest rating from the other two groups. Moreover, the likelihood of switching to other service providers is greater for heavy users in comparison to light or medium users. The various effects of an ISP's service quality aspects (i.e. network quality, customer service, information support, privacy and security) on customers' intention to switch among the three segments of Internet users also deservetheISPs' attention.The findings can be utilised to design marketing strategies targeting specific market segments. For example, in order to decrease the churn rate, companies need to ensure good network quality for medium and heavy users, whereas emphasis on information support should be given to light users.

Furthermore, the findings demonstrate that all of the three usage groups consider Internet service performance, customer service, and promotional package as the top three motivations for switching. However, each of the groups attaches different levels of importance to the three reasons. For example, while heavy users consider a failure of Internet service performance as the primary reason for changing service providers, poor Internet performance and customer service are almost equally chosen by medium users and light users as their rationale for switching.

In general, this study proposes that firms can build customer retention by providing outstanding Internet service performance, good customer service, and reasonable promotional packages, which are critical for an ISP's success and long term sustainability. As respondents in this study pay less attention to price, competing on price is not recommended for ISPs. Moreover, ISPs should address the issues that are relevant to specific customer segments in order to maximise the use of its resources and become more market oriented. For instance, promotion programs should target light users rather than heavy users who focus more on network quality. ISPs should leverage on these findings in order to enhance customer retention. Finally, it is highlighted that ISPs can achieve success by designing and implementing marketing strategies which place customers central in their day to day operations. Beneficiaries of this study are various stakeholders in Thailand, including consumers of ISPs, ISPs themselves, the government, and other commercial interests.

\section{References}

ACMA. (2012),"Internet use and social networking by young people”,Media and Communications in Australian Families series, Retrieved 1/04/2014, from http://www.acma.gov.au/webwr/_assets/main/lib310665/no1_internet_use_social_netw orking_young_people.pdf.

Alba, J. W.and Hutchinson, J. W. (1987), “Dimensions of consumer expertise”,Journal of Consumer Research, vol. 13, no. 4, pp. 411-454.

Altman, I.and Taylor, D. A. (1973), Social Penetration: The Development of Interpersonal Relationships, New York, NY: Holt, Rinehart and Winston. 
Assael, H. (2005), “A demographic and psychographic profile of heavy internet users and users by type of internet usage", Journal of advertising research, vol. 45, no. 1, pp. 93123.

Aydin, S.and Özer, G. (2005), "The analysis of antecedents of customer loyalty in the Turkish mobile telecommunication market”,European Journal of Marketing, vol. 39,no. 7/8, pp. 910-925.

Chiou, S. (2004),"The antecedents of consumers' loyalty toward Internet Service Providers", Information and Management, vol. 41, pp. 685-695.

Christodoulides, G.and Michaelidou, N. (2010),"Shopping motives as antecedents of esatisfaction and e-loyalty”, Journal of Marketing Management, vol. 27, no. 1/2, pp. 181197.

CIA. (2013),"The world factbook",CIA, Retrieved 1st August, 2013, from https://www.cia.gov/library/publications/the-world-factbook/geos/th.html

Cooil, B., Keiningham, T. L., Aksoy, L.and Hsu, M. (2007),“A longitudinal analysis of customer satisfaction and share of wallet: investigating the moderating effect of customer characteristics", Journal of Marketing, vol. 71, no. January, pp. 67-83.

Crown, W. H. (1998), Statistical models for the social and behavioral sciences: Multiple regression and limited-dependent variable models. Greenwood Publishing Group.

Czepiel, A. J. (1990), Service encounters and service relationships: implications for research. Journal of Business Research, vol. 20, no.1, pp. 13-21.

Dagger, T. S.and O'Brien, T. K. (2010),“Does experience matter?: Differences in relationship benefits, satisfaction, trust, commitment and loyalty for novice and experienced service users", European Journal of Marketing, vol. 44, no. 9/10, pp. 1528-1552.

Dagger, T. S.and Sweeney, J. C. (2007), "Service quality attribute weights how do novice and longer-term customers construct service quality perceptions", Journal of Service Research, vol. 10, no.1, pp. 22-42.

Dahlen, M. (2002),"Learning the web: Internet user experience and response to web marketing in Sweden", Journal of Interactive Advertising, vol. 3, no. 1, pp. 25-33.

ETDA. (2013), "Thailand Internet User Profile 2013”, ETDA, 15/05/2014, from http://www.etda.or.th/etda_website/files/system/InternetUserProfile_2013_14.11.13.pd $\mathrm{f}$

Fulps, L. (2013), “College students' heavy Internet use shares symptoms of addiction”, MST, 3/02/2014, from https://news.mst.edu/2013/12/college-students-heavy-internet-useshares-symptoms-of-addiction/

Han, S., Lu, S.and Leung, S. (2012), "Segmentation of telecom customers based on customer lifetime value by decision tree model", Expert Systems with Applications, vol. 39, pp. 3964 - 3973.

Heckmann, O. (2007), The competitive Internet service provider: network architecture, interconnection, traffic engineering and network design: John Wiley and Sons.

Hsee, C. K. (1996),"The evaluability hypothesis: an explanation for preference reversals between joint and separate evaluations of alternatives", Organizational Behavior and Human Decision Processes, vol. 67, no.3, pp. 247-257.

IWS. (2013),“Asia Marketing Research, Internet Usage”, Population Statistics and Facebook Information, Retrieved 4th November, 2013, from http://www.internetworldstats.com/asia.htm

Larkin, J. H., McDermott, J., Simon, D. P.and Simon, H. A. (1980),“Models of Competence in Solving Physics Problems", Cognitive Science, vol. 4, no. 4, pp. 317-345.

Maheswaran, D.and Sternthal, B. (1990), "The Effects of Knowledge, Motivation and Type of Message on Ad Processing and Product Judgments", Journal of Consumer Research, vol. 17 , no. June, pp. 66-73.

Marketline. (2014),“Asia-Pacific - Telecommunication Services”, Marketline, Retrieved 22 July 2014.

Mazzoni, C., Castaldi, L.and Addeo, F. (2007),“Consumer behavior in the Italian mobile telecommunication market”, Telecommunications Policy, vol. 31, no. 10/11, pp. 632647. 
Nielson. (2013),“Australian Connected Consumers Report”, Nielsen, 02/03/2014, from http://www.nielsen.com/content/dam/corporate/au/en/reports/2013/australianconnected-consumers-flyer-march-2013.pdf

Prentice, C. (2014), "Who stays, who walks, and why in high-intensity service contexts", Journal of Business Research, vol. 67, no. 4, pp. 608-614.

Saeed, A., Hussain, N. and Riaz, A. (2011), "Factors Affecting Consumers' Switching Intentions", European Journal of Social Sciences, vol. 19, no. 1, pp. 54-61.

Spiller, J., Vlasic, A.and Yetton, P. (2007), "Post-adoption behavior of users of Internet Service Providers", Information and Management, vol. 44, no.1, pp. 513-523.

Thaichon, P. and Quach, T. N. (2016), "Integrated Marketing Communications and Their Effects on Customer Switching Intention", Journal of Relationship Marketing, vol. 15, no. 1-2, pp. 1-16,

Thaichon, P.and Quach, T. N. (2013), "Integrated marketing communications and their influences on brand loyalty: A Thai perspective", International Journal of Studies in Thai Business, Society and Culture, vol. 2, no. 1, pp. 55-79.

Thaichon, P., Lobo, A.and Mitsis, A. (2014), “An Empirical Model of Home Internet Services Quality in Thailand", Asia Pacific Journal of Marketing and Logistics, vol. 26, no.2, pp. 190-210.

Tracey, S., Dagger, T.and O'Brien, K. (2010),"Does experience matter?: Differences in relationship benefits, satisfaction, trust, commitment and loyalty for novice and experienced service users", European Journal of Marketing, vol. 44, no. 9/10, pp. $1528-1552$.

Wedel, M.and Kamakura, W. (2003),Market segmentation. Conceptual and methodological foundations. Norwell, MA: Kluwer Academic Publishers.

Weinstein, A. (2002),"Customer retention: a usage segmentation and customer value approach", Journal of Targeting, Measurement and Analysis for Marketing, vol. 10, no. 3, pp. 259-268.

Wen-Hua S., Wu Z.and Jing-yi L. (2010), "Analysis of the influencing factors of users' switching intention in the context of one-way mobile number portability", The Journal of China Universities of Posts and Telecommunications, vol. 17, pp.112-117.

Zeithaml, V. A.and Bitner, M. J. (2003), Services Marketing: Integrating Customer Focus Across The Firm. New York: McGraw Hill.

Zeithaml, V. A., Berry, L. L.and Parasuraman, A. (1996), “The Behavioral Consequences of Service Quality", Journal of Marketing, vol. 60, no. 2, pp. 31-46. 